\title{
Evolution of the mantle root beneath the North Atlantic Craton
}

\section{Nadine Wittig $^{1}$, D. Graham Pearson ${ }^{1}$, Michelle Webb ${ }^{1}$, Chris J. Ottley ${ }^{1}$, Karina K. Sand ${ }^{2,3}$, Sven M. Jensen ${ }^{2,4}$ \& Geoff M. Nowell ${ }^{1}$}

\author{
${ }^{1}$ Department of Earth Sciences, Durham University, South Road, Durham, DH1 3LE, UK \\ ${ }^{2}$ Geological Survey of Denmark and Greenland, Øster Voldgade 10, 1350 Copenhagen, K, DK
}

${ }^{3}$ Nano-Science Center, Department of Chemistry, University of Copenhagen, Universitetsparken 5, 2100

${ }^{4}$ Crew Minerals ASA, Munkedamsvej 45F, PO Box 1416, Vika, 0115 Oslo, NO

\section{Introduction}

We present preliminary whole-rock major and trace element and Re-Os isotope systematics in addition to selected mineral Nd-Hf isotope data of garnet- and spinel-facies peridotite xenoliths $(n=60)$ that were sampled across a $\sim 700 \mathrm{~km} \mathrm{~N}$-S traverse of the North Atlantic Craton, West Greenland. The xenoliths were erupted at c. 560-600 and $164 \mathrm{Ma}$ and are dominated by peridotite lithologies, with eclogite being a very scarce component at all localities. The peridotites are harzburgitic to dunitic and comprise $<15 \%$ orthopyroxene and very little clinopyroxene $(<<5 \%$, Fig. 1). If garnet is present it occurs in variable amounts (8 to $0.3 \%$, Wittig et al., 2008) but is typically low in abundance.

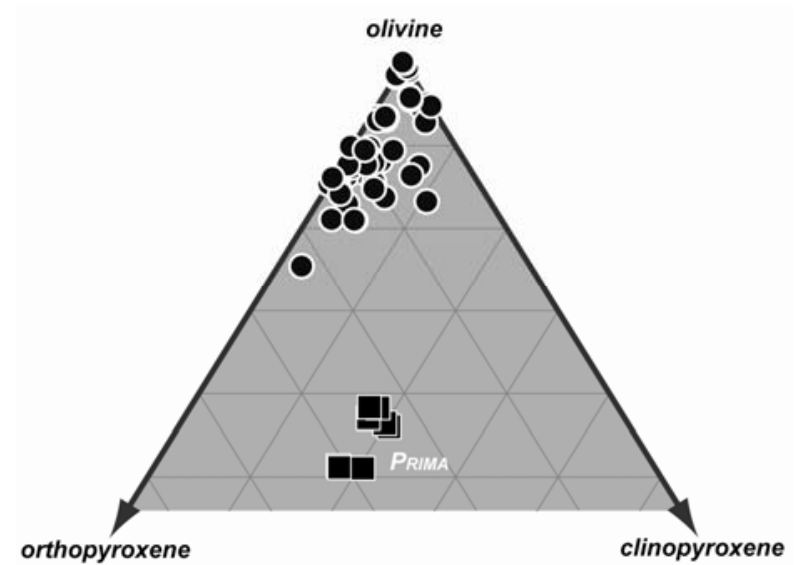

Fig.1 Mineral modes of NAC peridotites calculated by mass balance on large $(400 \mathrm{~g})$ samples.

Major element and trace element systematics Major element systematics of these peridotites are highly refractory with $\mathrm{Al}_{2} \mathrm{O}_{3}<<1.8 \mathrm{wt} \%$ and $\mathrm{Mg} / \mathrm{Si}$ ranging between 1.43 and 1.61 . FeO varies considerably (wt\% $6.4-16.5$ ) and does not correlate with LOI (loss on ignition), MgO or other major elements (Fig. 2). The elevated FeO in whole-rock peridotites is accompanied by relatively Fe-rich olivines (Mg\# as low as 84) and appears to result from melt/rock reaction leading to the precipitation of fayalite-rich olivine. The overall refractory character of the NAC continental mantle root sets these peridotites distinctly apart from those of other well studied cratonic roots such as the Kaapvaal Craton (Fig, 1 \& 2), but they are similar to, but more extreme than peridotites from Tanzania (Lee \& Rudnick, 1999) and the Zimbabwe craton (Smith et al. this volume).
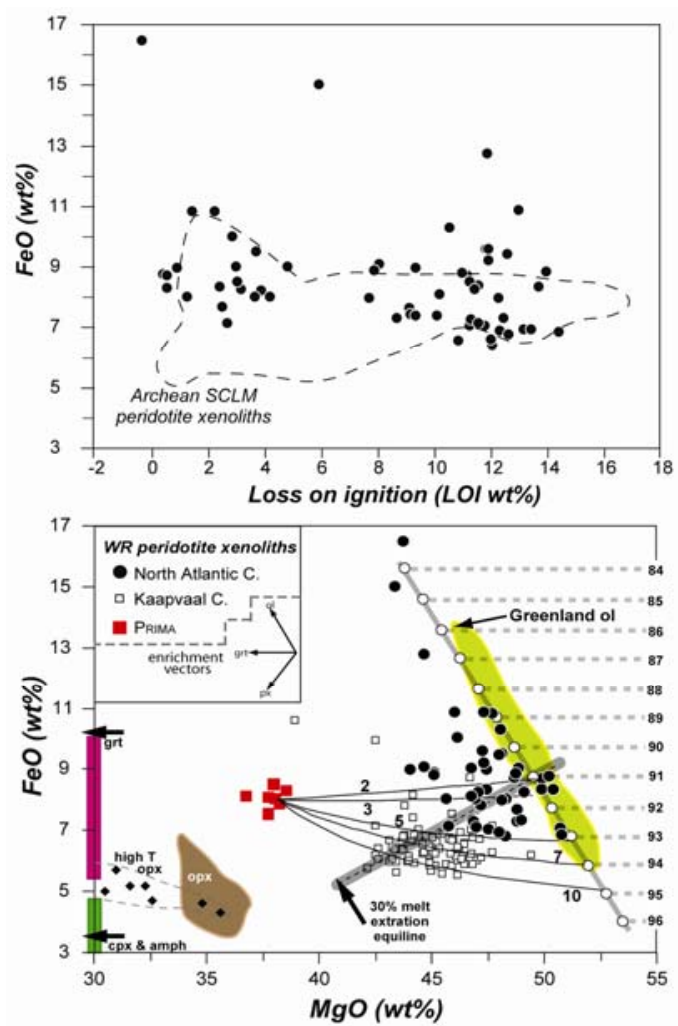

Fig.2 Whole-rock FeO vs LOI and MgO. Melting trends for various pressures shown in GPa. Also shown are mineral compositions to indicate the direction of modal metasomatic enrichment. 
Heavy rare earth element concentrations of whole rock peridotites are generally very low and consistent with numerical mantle melting models that suggest the complete removal of clinopyroxene, and the absence and/or complete removal of garnet during fractional polybaric mantle melting (Pearson \& Wittig, 2008; Wittig et al., 2008, Fig. 3). Such exhaustion of garnet and clinopyroxene is best reconciled in a shallow melting environment (i.e. $<3 \mathrm{GPa}$ ), possibly in a subduction- or mid-ocean-ridge-like setting as suggested for other cratons (Kelemen et al. 1998; Simon et al., 2007).

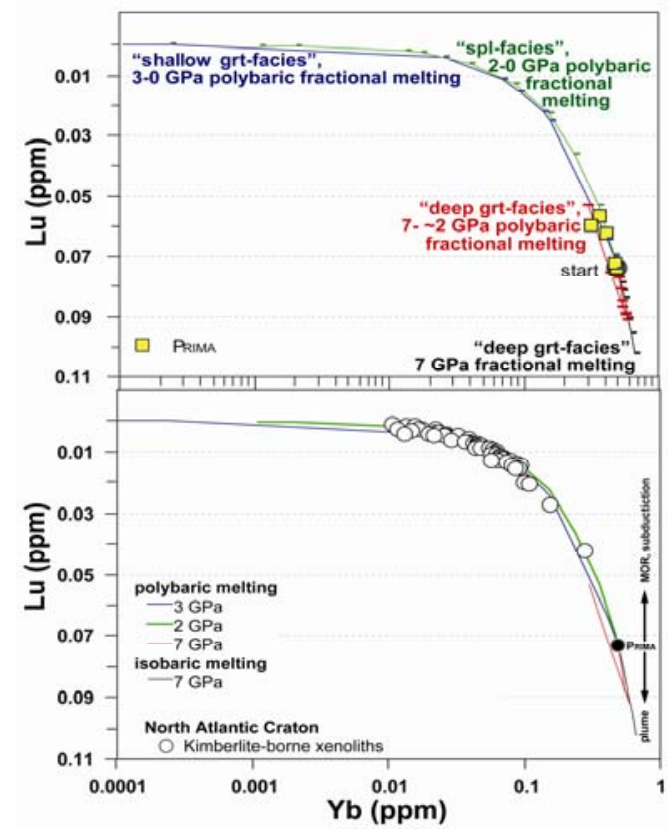

Fig.3 Lu vs Yb for calculated residues of "deep" and "shallow" polybaric of whole-rock peridotites. Pressures, in GPa, are those at which melting initiates. Details of modeling in Wittig et al., 2008.

\section{Os isotope and PGE abundance systematics}

Preliminary Os isotope ratios of whole-rock peridotites reveal a heterogeneous continental mantle root with $\gamma$ Os ranging between +3 and -14.1 . Generally, NAC peridotites show no variation of Os isotope ratios with indicators of melt extraction, e.g., $\mathrm{Al}_{2} \mathrm{O}_{3}$ (alumochron) or olivine modal abundance. Os isotopes suggest initial depletion at $\sim 3.0 \mathrm{Ga}$ although two dominant periods of melt extraction appear to have occurred later at approximately 1.8 and $2.8 \mathrm{Ga}$. These $\mathrm{T}_{\mathrm{RD}}$ model ages coincide with major crustal formation events occurring adjacent to and across the NAC.

Platinum-group elements (PGE) systematics are highly variable in the NAC SCLM. Samples from the northern NAC have very low P-PGE and low $[\mathrm{Pd} / \mathrm{Ir}]_{\mathrm{N}}$, in keeping with their very depleted major element compositions. These samples also have $[\mathrm{Pd} / \mathrm{Pt}]_{\mathrm{N}}$ ratios that are characteristic of Archean peridotites and are best reconciled with the consumption of base metal sulphides during melt extraction. A number of wholerock dunites from the southern NAC may have postArchean $\mathrm{T}_{\mathrm{RD}}$ model ages (e.g. $0.48 \mathrm{Ga}$ ), whereas their constituent olivines reveal Neoarchean $\mathrm{T}_{\mathrm{RD}}$ model ages (e.g., 2.57 Ga). This indicates substantial Os isotope re-setting on the whole rock scale in some samples. These samples are generally the most depleted in Pt, but Pd abundances often appear elevated compared to other PGE and Re. The Os isotope and PGE systematics of these southern peridotites suggest significant disturbance of siderophile elements on the whole-rock scale.

\section{Mineral trace element and Hf-Nd isotope data}

Trace element systematics in hand-picked and leached clinopyroxene separates from peridotites $(n=10)$ show remarkably similar, overall enriched primitive-mantle normalized patterns (Fig. 4). Garnet trace element patterns are significantly more variable. Samples devoid of clinopyroxene (i.e., harzburgites) have garnet displaying sinusoidal REE patterns, with low HREE abundances.

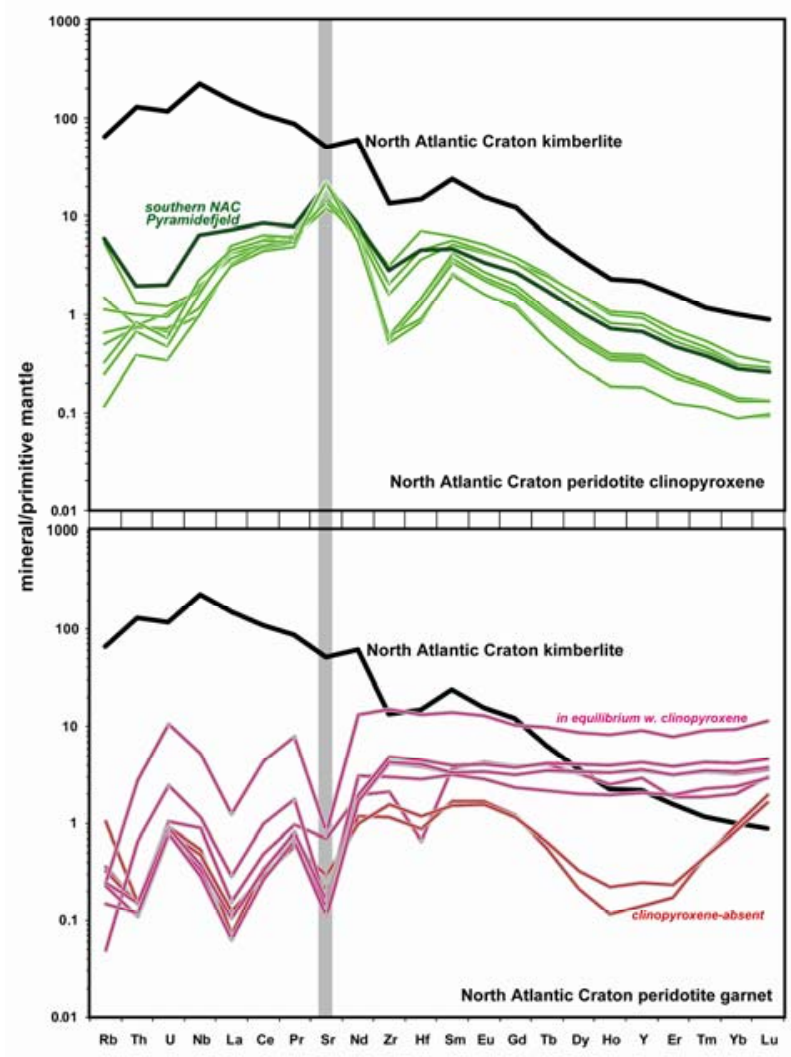

Fig.4 Primitive-mantle normalized trace element abundances of NAC peridotite garnet and clinopyroxene. Kimberlite after Gaffney et al., 2007.

The trace element systematics of most of these minerals (e.g., Sr anomalies, REE distribution) are consistent with precipitation from the kimberlitic host volcanic rocks from the NAC, a notion strongly supported by the Hf-Nd isotope systematics. Clinopyroxene in a single sample from the southern NAC has very similar multi-element systematics to clinopyroxenes from further North, although somewhat stronger enrichment in very incompatible elements and slightly more radiogenic $\varepsilon \mathrm{Hf}$ is evident (Fig. 5). The harzburgitic garnet with the sinusoidal trace element pattern exhibits significantly more radiogenic Hf isotopes ( $\varepsilon \mathrm{Hf} \sim 50$, Fig. 5) than garnets within 
lherzolites from the same region. This sample possibly testifies to an earlier, although volumetrically insignificant, re-enrichment event of the NAC SCLM. Garnet separated from the exterior portion of this xenolith is more enriched in Rb, $\mathrm{Zr} \& \mathrm{Hf}$, and MREE than garnet from the center of the nodule. This possibly indicates chromatographic fractionation of passing metasomatic liquids and the corresponding mineral precipitates.

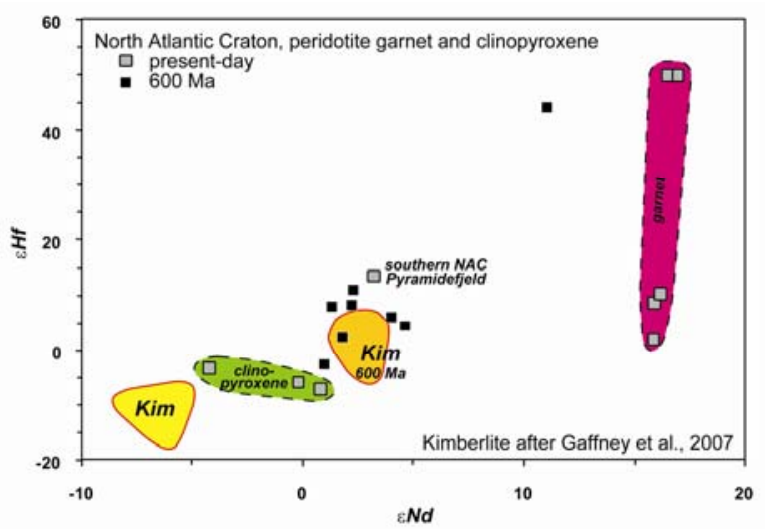

Fig. 5 \&Hf vs $\varepsilon N d$ of NAC peridotite garnet and clinopyroxene.

Present-day Nd-Hf isotope systematics of garnet $(\varepsilon \mathrm{Nd}$ +3 to $+17 ; \varepsilon \mathrm{Hf}+2$ to 26$)$ and clinopyroxene ( $\varepsilon \mathrm{Nd}-5$ to +3 ; $\varepsilon \mathrm{Hf}-7$ to +13 ) recovered from NAC peridotites are variable but generally unremarkable compared with the considerable Hf-Nd isotopic variation recorded in some lithospheric peridotites (e.g., Bedini et al., 2004, Carlson et al., 2004; Simon et al., 2007). Initial Hf-Nd isotopic compositions are much less varied still and, with the exception of the harzburgitic garnet, cluster around the composition of the host kimberlites (Gaffney et al., 2007). In fact, co-exisiting garnetclinopyroxene yield the same $\mathrm{Nd}$ isotope initial as the host kimberlites $\left({ }^{143} \mathrm{Nd} /{ }^{144} \mathrm{Nd} \sim 0.511993\right)$ and their Sm$\mathrm{Nd}$ isotope systematics indicate co-precipitation at 556 and 582 Myr. These ages coincide with two episodes of kimberlite volcanism at the northern margin of the NAC determined by zircon U-Pb ages (Heaman, 2005, 568-556 Ma \& 585-577 Ma) and very strongly suggest that the majority of garnet and clinopyroxene found in northern NAC peridotites formed as a result of kimberlite metasomatism. Lu-Hf isotope data of one garnet-clinopyroxene pair suggests either closure, and hence eruption at a younger age ( $\sim 02 \mathrm{Ma})$, or that the mineral pair was not in isotopic equilibrium. This mineral trace element and Hf-Nd isotope data is consistent with a metasomatic/metamorphic origin of garnet and clinopyroxene in the NAC continental mantle root predominantly as a result of kimberlite volcanism.

\section{Summary}

The NAC continental mantle root beneath $\mathrm{W}$. Greenland is comprised of highly refractory harzburgites and dunites with minor metasomaticallyformed clinopyroxene and garnet. This lithosphere is perhaps the least orthopyroxene-rich of any craton, with the possible exception of the Zimbabwe craton (Smith et al., this volume) and the dunitic/low opxharzburgite mineralogy may represent that of cratonic lithosphere prior to extensive modal metasomatism/ silica enrichment. Whole-rock trace element data requires original high degrees of melt depletion (to cpx and garnet exhaustion) in a shallow melting environment (3 GPa or less) and Os isotope data shows that in most samples the initial mantle melting occurred $>2.5$ Gyr. Some residues appear to have formed in later tectono-magmatic events associated with the Proterozoic evolution of the NAC.

\section{References:}

Bedini, R.M., Blichert-Toft, J., Boyet, M. and Albarede, F., 2004. Isotopic constraints on the cooling of the continental lithosphere. Earth and Planetary Science Letters, 223: 99-111.

Carlson, R.W., Irving, A.J., Schulze, D.J. and C., H.J.B., 2004. Timing of Precambrian melt depletion and Phanerozoic refertilization events in the lithospheric mantle of the Wyoming Craton and adjacent Central Plains Orogen. Lithos 77: 453472.

Heaman, L. M., 2005. Patterns of kimberlite emplacement the importance of robust geochronologyWorkshop on Greenland's diamond potential. Danmarks og Gronlands Geologiske Undersogelse Rapport 2005/68, Copenhagen.

Gaffney, A.M. et al., 2007. Constraints on source-forming processes of West Greenland kimberlites inferred from Hf-Nd isotope systematics. Geochimica et Cosmochimica Acta 71: 22-238.

Kelemen, P.B., Hart, S. and Bernstein, S., 1998. Silica enrichment in the continental upper mantle via melt/rock reaction. Earth and Planetary Science Letters 164: 387-406.

Lee, C.-T. and Rudnick, R.L., 1999. Compositionally stratified cratonic lithosphere: petrology and geochemistry of peridotite xenoliths from the Labait tuff cone, Tanzania. In: J.J. Gurney and S.R. Richardson (Editors), 7th International Kimberlite Conference, Cape Town, pp. 503-522.

Pearson, D.G. and Wittig, N., 2008. Formation of Archean continental lithosphere and its diamonds: The root of the problem. Journal of the Geological Society, London, 165: 1-22.

Simon, N., Carlson, R.W., Pearson, D.G. and Davies, G.R., 2007. The origin and evolution of the Kaapvaal cratonic lithospheric mantle. Journal of Petrology 48: 589-625.

Smith, C. B., Pearson, D. G., Bulanova, G. P., Beard, A. D., Carlson, R. W., Sims, K., Chimuka, L., and Muchemwa, E., 2008. Extremely depleted lithospheric mantle and diamonds beneath the southern Zimbabwe Craton 9th International Kimberlite Conference, Frankfurt, this volume

Wittig, N., Pearson, D. G., Webb, M., Ottley, C. J., Irvine, G. J., Kopylova, M., Jensen, S. M. and Nowell, G. M.,2008. Origin of cratonic lithospheric mantle roots: A geochemical study of peridotites from the North Atlantic Craton, West Greenland. Earth and Planetary Science Letters. 